\title{
Notebooks and Namaste: Yoga and Teacher Self-Care
}

\section{Valerie Hill-Jackson*}

Texas A\&M University, USA

Submission: March 05, 2018; Published: August 28, 2018

*Corresponding author: Valerie Hill-Jackson, Texas A\&M University, USA, Email: vhjackson@tamu.edu

\section{Opinion}

A report by the American Federation of Teachers (2017) recently made headlines with the finding that 61 percent, nearly two out of every three teachers, is often or always stressed out due to the demands of their profession. After three decades since the alarm was first sounded [1] the silent epidemic of stress among educators continues with no authentic or supportive response. Benson [2] demands that we move beyond well-intentioned conversations about teacher stress and care and insert more robust in-school support systems. The self-care revolutionactions to preserve or enhance one's life, health, and well-being [3]-has given rise to various stress relieving techniques, such as yoga, among educators [4]. This truncated opinion article seeks to shed a little light on teacher stress and lobby for the growing trend of yoga in the teaching profession while articulating the implications of yoga therapy among PreK-12 educators.

\section{Teacher Stress}

Stress is defined as mental or emotional strain after an adverse life event. "Stress is the subjective experience of negative emotional states coupled with physiological activation that often produces uncomfortable physical sensations" [5]. For teachers, stress is the result from occupational burnout [6] and personal traumas [7]. The causes of teachers' occupational stress are generally well known, such as: the demands of leadership and the school organization, burdens of the job, availability and access to resources, and social emotional competence of teachers and students [6]. The overall impact of occupational teacher stress results in lower performance, poor health or lack of well-being, increased absenteeism, or higher turnover.

Relatedly, the indirect consequences of teacher stress are decreased student achievement, lower continuity for students and parents, and higher educational costs due to teacher attrition and training. Likewise, if a teacher is struggling with a personal stressor at home, that problem is likely to follow him or her into the classroom [8]. The teacher withstands such private burdens as: death of loved ones, substance abuse, domestic violence, anger management issues, divorce, complexities in parenting and balancing family/home life, chronic illness, anxiety, burnout, depression caused by a lack of professional fulfillment, discrimination, financial pressures, and/or a combination of two or more of these difficulties.

Although this represents only a partial list of the hazards that can make teaching overwhelming, the message is clear: The demands on teachers as helping professionals is challenging and often difficult for reasons beyond their control. A stressful life, in and out of school, often affects how teachers support learners and manage their own self-care.

Yoga and the PreK-12 Teacher

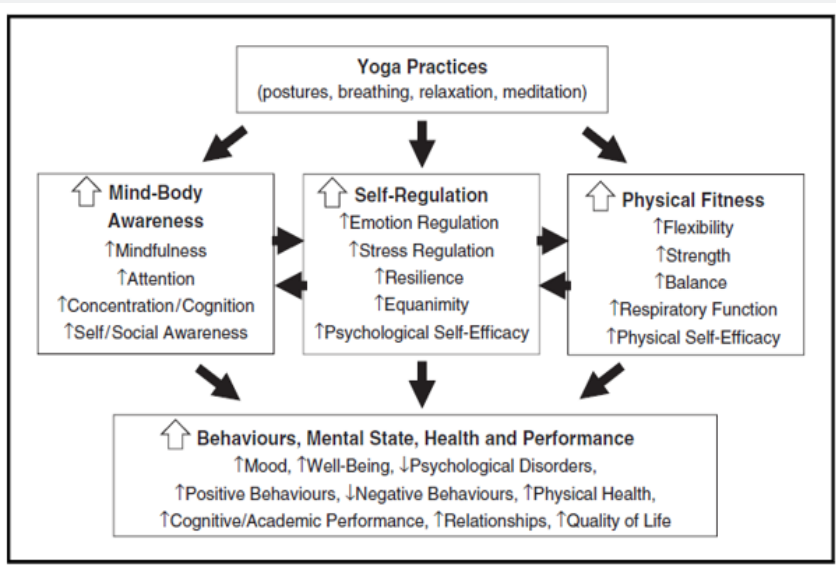

Figure 1: Hypothesized associations between yoga practice, self-regulation, mind-body awareness, physical fitness, performance, health, mental state and behaviors (Butzer, Bury, Telles, \& Khalsa, 2016, p. 8). Reproduced with permission. 
While there are many traditions of yoga $[5,9]$ describe yoga as a universal term that comprises "breathing techniques, postures, strengthening exercises, and meditation". In an effort to address learning for the whole child, approaches for socially, emotionally, and cognitively adept learners [10], a growing movement to include yoga in schools has emerged. The yoga curriculum in schools diverges from traditional or critical subject matter in that it underscores a "light touch on others and the world" [11]; the emphasis is on understanding self and one's internal connections to the environment. Scholars make the natural connection between yoga and the increase in students' socio-emotional grit; arguing that such activities improve their focus and self-regulation [4]. The chief outcomes of yoga for PreK-16 learners are mind-body awareness, self-regulation, and physical fitness. Over time, the long-term effects may lead to an increase in more positive behaviors among learners, an upturn in mood with an overall sense of well-being, improved cognitive functioning, and growth in physical efficacy (Figure 1).

The discussion of yoga in schools has almost exclusively focused on building students' mindfulness and self-care. However, teachers who work with students to develop their socio-emotional competence may also benefit from yoga selfcare techniques. Yoga programming that works well for PreK-12 learners can be equally advantageous for PreK-12 teachers for managing occupational and personal stress. Reducing teachers' stress levels may give them more energy, enhance their immune system, and lower the risk of burnout and depression. Being intentional about self-care through yoga makes educators more resilient because it helps them remain unflappable when school and personal crises arise. Yoga helps educators improve classroom performance because they can focus better on learners, have a high sense of efficacy, and distinguish between the daily-ness of school bureaucracy from what really matters. Overall, yoga as a self-care intervention allows teachers to recenter in order to bounce back after stressful situations [4]. Yoga may help educators experience a greater sense of fulfillment, and ultimately serve as a conduit to self-care in order to build resiliency [7].

\section{Implications: Yoga and the Emotionally Intelligent Teacher}

The repercussions of teacher stress are magnified because, as helping professionals, educators are natural caregivers and are required to give so much of themselves [12]. Many teachers, due to extreme pressures, often choose to leave the profession; nearly thirty percent of all new teachers are gone by year three and nearly fifty percent are gone by year five [13]. Additionally, teacher preparation programs are criticized for focusing too much on knowledge development and not enough on personal reflection of one's self and larger purpose and how to seek meaning in one's life ... However, neuroscience, learning theory, and teaching experience all illustrate that the social and emotional dimensions of learning are not only inextricably linked to academic success, but are indeed at its very foundation [14].
Social-emotional competence is equally as important as cognitive astuteness in order for educators to perform well in schools and classrooms [15]. Emotional intelligence is one's ability to: perceive accurately; appraise and express emotion; access and/or generate feelings when they facilitate thought; and regulate emotions to promote emotional and intellectual growth [16]. "In addition to technical expertise, 21st century teachers and teacher-leaders need a steady supply of passion, heart, and inner resiliency to resist burnout and effectively respond to the curricular, societal, and institutional conditions of teaching" (Michalec, as cited in Dorman, 2015, p. 104). The more emotionally astute the teacher, the greater the likelihood that he or she is able to rebound from harsh personal circumstances and become more effective in the classroom.

Powell \& Kusuma-Powell [17] propose "that a high degree of teacher emotional competence is a prerequisite in any highquality classroom" (p. 6). How can educators inspire or lead learners to be socio-emotionally competent if they have not bought into, or utilize for themselves, self-care techniques? Teachers must be leaders in self-development if any progress is to be made among PreK-12 learners [18]. Failure to find mediating ways to support our teachers' emotional sturdiness may hinder the development of students' socio-emotional development; whole child learning tactics, such as yoga, might be emulated by the teacher self-care movement [19].

\section{Conclusion}

Teachers encounter workplace and private ordeals that places them at-risk for experiencing stress and burnout. Consequently, teachers must engage in active attempts to effectively manage the occupational and personal challenges through ongoing selfcare efforts [20]. Yoga has sound conceptual underpinnings and growing empirical support for alleviating stress among PreK12 educators. Failure to find mediating ways to support our teachers' emotional sturdiness may further erode the teaching population [21]. Further, physical and mental wellness for learners begins with physical and mental wellness for their teachers. Quite simply-when our teachers are well, our students are well.

\section{References}

1. Farber BA (1991) Crisis is education: Stress and burnout in the American teacher: Jossey-Bass, San Francisco, United States.

2. Benson J (2018) When teacher self-care is not enough. Educational Leadership 75(4): 38-42.

3. Skovholt TM, Trotter-Mathison M (2011) The resilient practitioner: Burnout prevention and self-care strategies for counselors, therapists, teachers, and health professionals ( $2^{\text {nd }}$ edn), Taylor \& Francis, New York, USA.

4. Deitz R, Rajan S (2017) Access and barriers to implementing yogabased interventions for at-risk adolescent youth. International Journal of Health Promotion and Education 55(1): 30-41.

5. Khanna J, Greeson JM (2013) A narrative review ofyoga and mindfulness as complementary therapies for addiction. Complementary Therapy Medicine 21(3): 244-252.

6. Greenberg MT, Brown JL, Abenavoli RM (2016) Teacher stress and health effects on teachers, students, and schools. Edna Bennett Pierce 
Prevention Research Center, University Park, Pennsylvania State University, Pennsylvania, USA.

7. Hill-Jackson V (2018) Teacher confidential: Personal stories of stress, self-care, and resilience. iUniverse, Bloomington, USA.

8. Pajak E, Blasé JJ (1989) The impact of teachers' personal lives on the professional role enactment: A qualitative analysis. American Educational Research Journal 26(2): 283-310.

9. Khalsa SB (2006) A perennial debate. International Journal of Yoga Therapy16(1): 5-6.

10. Noddings $\mathrm{N}$ (2005) What does it mean to educate the whole child? Educational leadership 63(1): 8.

11. Hyde AM (2012) The yoga in schools movement: Using standards for educating the whole child and making space for teacher self- care. In: Porfilio B, Gorlewski DA (Eds.), Using standards and high- stakes testing for students: Exploiting power with critical pedagogy, Peter Lang Publishing, New York, USA.

12. Fleming JL, Mackrain M, LeBuffe PA (2011) Caring for the caregiver: Promoting the resilience of teachers. In: S Goldstein \& R. B. Brooks (Eds.), Handbook of resilience in children ( $2^{\text {nd }}$ edn), Springer, New York, USA, pp: 387-398.

13. Ingersoll R, Merrill L, Stuckey D (2014) Seven trends: The transformation of the teaching force. CPRE Research Reports.

This work is licensed under Creative Commons Attribution 4.0 License

DOI: $10.19080 / J Y P .2018 .06 .555679$
14.Dorman E (2015) Building teachers' social-emotional competence through mindfulness practices. In: DJ Flinders, PB Uhrmacher (Eds.), Curriculum and teaching dialogue, NC: Information Age Publishing, Charlotte, USA, pp: 103-119.

15. Brackett MA, Caruso DR (2006) The emotionally intelligent teacher. Quest Education, Ann Arbor, Michigan, USA.

16. Mayer JD, Salovey P (1997) What is emotional intelligence? In: Salovey P, Sluyter D (Eds.), Emotional development and emotional intelligence: Educational implications, New York, USA, p: 3-31.

17. Powell W, Kusuma-Powell O (2010) Becoming an emotionally intelligent teacher. Thousand Oaks, Corwin, California, USA.

18. American Federation of Teachers (AFT) (2017) Survey: Teacher jobs are less stressful in a collaborative environment.

19. Butzer B, Bury D, Telles S, Khalsa SBS (2016) Implementing yoga within the school curriculum: A scientific rationale for improving social-emotional learning and positive student outcomes. Journal of Children's Services 11(1): 3-24.

20. Shonkoff JP, Garner AS, Siegel BS, Dobbins MI, Earls MF, et al. (2012) The lifelong effects of early childhood adversity and toxic stress. Pediatrics 129(1): e232-e246.

21. Sutcher L, Darling-Hammond L, Carver-Thomas D (2016) Coming crisis in teacher education? Teacher supply, demand, and shortages in the U.S. Palo Alto, Learning Policy Institute, California, USA.

Your next submission with Juniper Publishers
will reach you the below assets
- Quality Editorial service
- Swift Peer Review
- Reprints availability
- E-prints Service
- Manuscript Podcast for convenient understanding
- Global attainment for your research
- Manuscript accessibility in different formats
( Pdf, E-pub, Full Text, Audio)
- Unceasing customer service
Track the below URL for one-step submission
https://juniperpublishers.com/online-submission.php

